\title{
$\mathrm{BaO}-\mathrm{Fe}_{2} \mathrm{O}_{3}$ 系ガラスの熱処理による ESR \\ ならびにメスバゥアースペクトルの変化
}

田 中 勝 久 $^{*}$ 吉 本 護**
大田 陸 夫 $^{* * *}$ 曾 我直 弘

\section{Change on ESR and Mössbauer Spectra through the Heat Treatment Process in $\mathrm{BaO}-\mathrm{Fe}_{2} \mathrm{O}_{3}$ Glass}

by

\author{
Katsuhisa TANAKA*, Mamoru Yoshimoto**, Rikuo OTA*** \\ and Naohiro SogA***
}

$0.6 \mathrm{BaO}-0.4 \mathrm{Fe}_{2} \mathrm{O}_{3}$ glass was prepared by twin-roller quenching method and its heat treatment process was examined by ESR and Mössbauer spectroscopy. $\mathrm{Fe}^{3+}$ ions were found to occupy distorted tetrahedral sites in this glass. $\mathrm{BaFe}_{2} \mathrm{O}_{4}$ and $\mathrm{Ba}_{2} \mathrm{Fe}_{2} \mathrm{O}_{5}$ were precipitated through the heat treatment at a temperature of $440^{\circ} \mathrm{C}$. The former is an antiferromagnetic crystal having Néel temperature of $880 \mathrm{~K}$. Before the crystallization occurred, the linewidth of ESR spectrum decreased monotonously although neither isomer shift nor quadrupole splitting changed. It was considered that in this region $\mathrm{Fe}^{3+}-\mathrm{O}^{2-}-\mathrm{Fe}^{3+}$ bond angle dominantly changed as a result of thermal relaxation of structure. When the crystallization occurred, both isomer shift and quadrupole splitting decreased significantly. These facts indicated that $\mathrm{Fe}^{3+}-\mathrm{O}^{2-}$ distance was longer in the glass than in the precipitated crystals and that the coordination state of $\mathrm{O}^{2-}$ ions around $\mathrm{Fe}^{3+}$ was more distorted in the glass.

Hyperfine field increased with increasing heat treatment temperature. This phenomenon was explained by considering the size of crystallized $\mathrm{BaFe}_{2} \mathrm{O}_{4}$ particles.

キー・ワード : ESR, メスバウアー効果, ガラス, 結晶化

\section{1 緒言}

遷移金属イオンを比較的高濃度に含有した酸化物市 るいはフッ化物ガラスは, スピンが空間的にランダム そゆらいだ系の一つとして, 極めて興味深い磁気的性 質を示す.これまでにこの種のガラスの磁気転移の様 子が主として帯磁率の測定から明らかにされてきたが， それによると磁気転移は低温で観察され，いわゆるス ピングラス的である. 一方, この種のガラスは系や組 成を適当選択すれば強磁性を発現する可能性もあり, ガラスの透光性と組み合せることにより，アモルファ ス光磁性材料としての用途が開けることも期待できる. このような意味で遷移元素高含有ガラスに括ける遷移 金属イオンの化学的状態や磁気的構造は, ガラスの磁 気的性質との関連で興味が持たれる. 本研究では, 遷 移元素高含有ガラスの局所構造特よび磁気的性質を結 晶状態のそれらと比較し, 類推する目的で, 超急冷法 で得た $0.6 \mathrm{BaO}-0.4 \mathrm{Fe}_{2} \mathrm{O}_{3}$ ガラスの結晶化過程を, ESR およびメスバゥアー分光法により追跡した。さ らに, 結晶析出前の熱処理によるガラスの熱的構造緩
和について子検討し, 総合的に, $0.6 \mathrm{BaO}-0.4 \mathrm{Fe}_{2} \mathrm{O}_{3}$ ガラスの熱処理にともなら鉄イオンの化学的状態と磁 気的性質の変化に関して考察を行った.

\section{2 実 験 方 法}

\section{$2 \cdot 1$ ガラスの合成と熱処理}

出発物質として特級の $\mathrm{BaCO}_{3}$ と $\mathrm{Fe}_{2} \mathrm{O}_{3}$ を用い, これらを目的の組成となるように $3 \mathrm{~g}$ ひょう量したの ち, 乳鉢で十分混合した. 混合物は静水圧下で成型後, 空気中， $900{ }^{\circ} \mathrm{C} て ゙ 3$ 時間焼結した。 得られた焼結体は キセノンランプを光源とするイメージ悷により, 空気 中, 約 $2000^{\circ} \mathrm{C}$ 妿熱溶融した. 融液は，3000 rpm で回転しているステンレス・スチール製の双ローラー 上に自由落下させ，約 $105 \mathrm{k} / \mathrm{s}$ の冷却速度で超急冷し た. 得られた試料は厚さが約 $20 \mu \mathrm{m}$ の薄片状であった。 試料がガラスであるか否かは, 粉末X線回折法 (X線 源：CuK $\alpha$ 線）により調べた.

ガラスの熱処理は通常の電気炉 $\frac{2}{14115)}$ 用 $300 \sim 700^{\circ} \mathrm{C}$ の種々の温度で各 5 時間加熱することによ り行った．熱処理にともなって析出した結晶相の同定

$\dagger \quad$ 原稿受理 昭和61年 3 月27日 Received Mar.27, 1986

* 京都大学大学院 京都市左京区吉田本町, Graduate Student, Kyoto University, Yoshida-hommachi, Sakyo-ku, kyoto

** 京都大学工学部 京都市左京区吉田本町, Faculty of Engineering, Kyoto University, Yoshida-hommachi, Sakyo-ku, Kyoto

*** 正会員 京都大学工学部 京都市左京区吉田本町, Faculty of Engineering, Kyoto University, Yoshida-hommachi, Sakyo-ku, Kyoto 
には粉末X線回折法を用いた.

\section{$2 \cdot 2$ ESR ならびにメスバウアー効果の測定}

熱処理前のガラスおよび熱処理後の各試料について は, ESR とメスバウアー効果の測定を，いずれも室 温で行った. ESR は測定装置として JEOL PE-2X を 使用し，X-バンド（振動数 $9.4 \mathrm{GHz}$ ) のマイクロ波 を用いて測定した.スペクトルの線幅预よび $g$ 值を決 定する際の標準物質として $\mathrm{MgO}$ 中にドープした $\mathrm{Mn}^{2+}$ の 6 本のシグナルを用いた.

メスバウアー効果の測定は $\gamma$ 線源として，10 $\mathrm{mCi} の$ ${ }^{57} \mathrm{Co}$ を金属ロジウム中にドープしたものを用いて行っ た. ドップラー速度の目盛の決定和よび異性体シフト の計算には， $\alpha-\mathrm{Fe}$ 薄膜の 6 本のスペクトル線を標準 として用いた。

\section{3 結果と考察}

\section{$3 \cdot 1$ 熱処理にともなうメスバウアースペクトルの 変化}

超急冷法によるガラス生成において，共晶点付近の 組成がガラス化しやすいことが，これまでに実験的に 確認されている. $\mathrm{BaO}-\mathrm{Fe}_{2} \mathrm{O}_{3}$ 系は，ガン法特よび単 ロール法によってガラス化が試みられているが，前者 によるガラス化領域は $30 \sim 60 \mathrm{~mol} \% \mathrm{Fe}_{2} \mathrm{O}_{3}$ の範囲で あり，後者では，38〜 $45 \mathrm{~mol} \% \mathrm{Fe}_{2} \mathrm{O}_{3}$ 抢よび 55〜70 $\mathrm{mol} \% \mathrm{Fe}_{2} \mathrm{O}_{3}$ の) 範团であって，いずれも $\mathrm{BaO}-\mathrm{Fe}_{2} \mathrm{O}_{3}$ 系の相平衡図に和ける共晶点組成を中心に広がってい る.そこで本研究においても，これらの組成領域を中 心に双ローラー法によるガラス化を試みた. その結果 を Fig. 1 に示す. 図から明らかなように安定なガラ スの得られたのは $40 \mathrm{~mol} \% \mathrm{Fe}_{2} \mathrm{O}_{3}$ の組成すなわち 0.6 $\mathrm{BaO0} .4 \mathrm{Fe}_{2} \mathrm{O}_{3}$ のみであり, 他の組成には結晶相が混 在した. 特に $\mathrm{Fe}_{2} \mathrm{O}_{3}$ が $60 \mathrm{~mol} \%$ の付近は, X線回折 図は全体的には八ローパターンを示し，この組成の試 料の大部分はガラス状態で存在すると考えられるが,

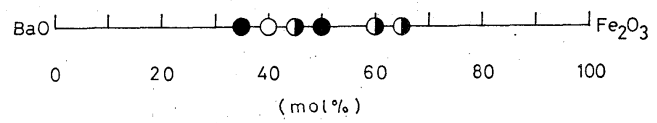

Fig. 1. Glass forming region in $\mathrm{BaO}-\mathrm{Fe}_{2} \mathrm{O}_{3}$ system by twin-roller method. $(\bigcirc$ : glass, : crystal, : glass + crystal)

おずかに $\mathrm{BaFe}_{12} \mathrm{O}_{19}$ によるピークが確認された。この ように双ローラー法によるガラス化領域が，ガン法な ぞに比べて狭くなるのは, 融液の冷却速度の差による ものであると思われる。

単ロール法によって作製された $0.4 \mathrm{BaO}-0.6 \mathrm{Fe}_{2} \mathrm{O}_{3}$ ガラスの結晶化にともなら磁気的性質の変化は既に報 告されている. それによると，このガラスからは $\mathrm{Ba}$ $\mathrm{Fe}_{2} \mathrm{O}_{4}$ をマトリックスとしてフェリ磁性の $\mathrm{BaFe}_{12} \mathrm{O}_{19}$ が析出し, その粒径が $800 \AA$ 付近で保磁力は最大に達
し，バルクのそれに比べて約 3 倍の保磁力を持つ.こ れらの報告では, ガラスからの結晶析出にともなら常 磁性, 超常磁性, フェリ磁性といった磁性の変化は調 ベられているが, 鉄イオンのまわりの局所構造の変化 や, 結晶析出前のガラスの熱的構造緩和については詳 しく調ベられていない. 本研究ではこれらの点を明ら かにする目的で, $0.6 \mathrm{BaO}-0.4 \mathrm{Fe}_{2} \mathrm{O}_{3}$ ガラスを対象に して実験を行った。

Table I は, 熱処理によって析出する結晶相をX線 回折により同定した結果である. 熱処理温度が $300^{\circ} \mathrm{C}$

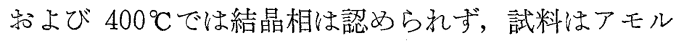
ファス状態である. 熱処理温度が $440{ }^{\circ} \mathrm{C}$ になると 2 種 類の結晶 $\mathrm{BaFe}_{2} \mathrm{O}_{4}$ と $\mathrm{Ba}_{2} \mathrm{Fe}_{2} \mathrm{O}_{5}$ が析出し, その後,

Table I. Precipitated crystals through the heat treatment process of $0.6 \mathrm{BaO}-0.4 \mathrm{Fe}_{2} \mathrm{O}_{3}$ glass.

\begin{tabular}{c|l}
\hline $\begin{array}{c}\text { Heat treatment } \\
\text { temperature }\left({ }^{\circ} \mathrm{C}\right) \\
\text { and time }(\mathrm{h})\end{array}$ & Results of X-ray diffraction \\
\hline $300^{\circ} \mathrm{C}, 5 \mathrm{~h}$ & Amorphous \\
$400^{\circ} \mathrm{C}, 5 \mathrm{~h}$ & Amorphous \\
$440^{\circ} \mathrm{C}, 5 \mathrm{~h}$ & $\begin{array}{l}\text { Precipitated } \mathrm{Crystals} \\
\mathrm{BaFe}_{2} \mathrm{O}_{4}, \mathrm{Ba}_{2} \mathrm{Fe}_{2} \mathrm{O}_{5}\end{array}$ \\
$500^{\circ} \mathrm{C}, 5 \mathrm{~h}$ & $\mathrm{BaFe}_{2} \mathrm{O}_{4}, \mathrm{Ba}_{2} \mathrm{Fe}_{2} \mathrm{O}_{5}$ \\
$600^{\circ} \mathrm{C}, 5 \mathrm{~h}$ & $\mathrm{BaFe}_{2} \mathrm{O}_{4}, \mathrm{Ba}_{2} \mathrm{Fe}_{2} \mathrm{O}_{5}$ \\
$700^{\circ} \mathrm{C}, 5 \mathrm{~h}$ & $\mathrm{BaFe}_{2} \mathrm{O}_{4}, \mathrm{Ba}_{2} \mathrm{Fe}_{2} \mathrm{O}_{5}$ \\
\hline
\end{tabular}

熱処理温度が上昇すると, これらの結晶のみが析出し た.これらのらち, $\mathrm{BaFe}_{2} \mathrm{O}_{4}$ はネール温度が $880 \mathrm{~K} の$ 反強磁性結晶である. $\mathrm{Fe}^{3+}$ はすべて酸素イオンの四 面体位置を占めている. 一方, $\mathrm{Ba}_{2} \mathrm{Fe}_{2} \mathrm{O}_{5}$ の磁気的性 質については，著者らの知る限り詳しい報告例はない が，後述すると和り少なくとも室温では常磁性を示す と思われる.ガラスからのこれらの結晶の析出にとも なら局所構造および磁気的性質の変化は，以下に示す ように特にメスバウアースペクトルに顕著に表れた.

Fig. 2 は実測された各試料のメスバウアースペクト ルを示す. まず，熱処理以前のガラスのスペクトルは 対称性の良い 2 本のピークのみから成り, 内部磁場の ゼーマン効果によるスペクトルの分裂は見られていな い. このことから，0.6 $\mathrm{BaO}-0.4 \mathrm{Fe}_{2} \mathrm{O}_{3}$ ガラスは室温 では常磁性体であることがわかる．このスペクトルか ら得られる異性体シフトと四極子分裂の值はそれぞれ $0.22 \mathrm{~mm} / \mathrm{s}$ および $0.81 \mathrm{~mm} / \mathrm{s}$ であった. 異性体シフ トの值から，このガラス中では鉄イオンはすべて $\mathrm{Fe}^{3+}$ の状態で存在し，その酸素配位数は 4 であることがわ かる.この異性体シフトの值は, 単ロール法で得られ た $0.6 \mathrm{BaO}-0.4 \mathrm{Fe}_{2} \mathrm{O}_{3}$ ガラスの値とよく一致している。 これに対して四極子分裂の值 $(0.81 \mathrm{~mm} / \mathrm{s})$ は，単口 ール法で得られた值 $0.91 \mathrm{~mm} / \mathrm{s}^{17)} よ り$ ，少し相違して 


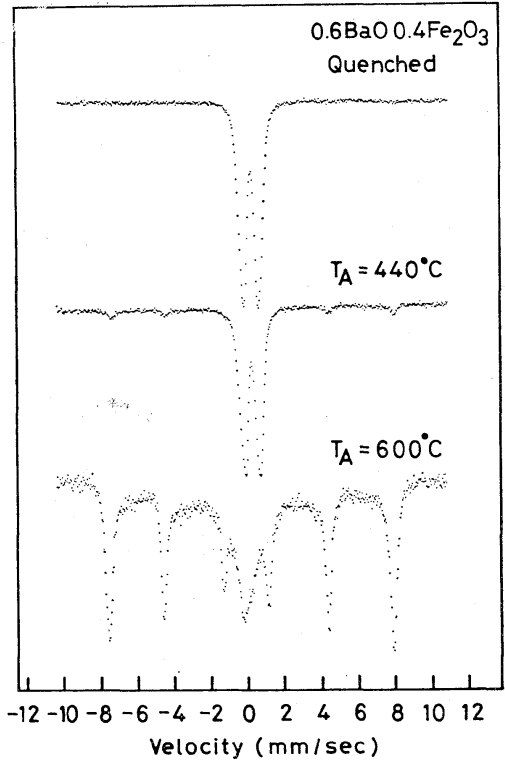

Fig. 2. Mössbauer spectra of quenched, heattreated at $440^{\circ} \mathrm{C}$, and heat-treated at $600^{\circ} \mathrm{C}$ $0.6 \mathrm{BaO}-0.4 \mathrm{Fe}_{2} \mathrm{O}_{3}$ glass. $T_{A}$ means the heat treatment temperature.

いる，これは両者の冷却速度の違いによるるのである と考えられる. 冷却速度の遅い双ローラー法では冷却 過程でガラス構造の緩和が括こりやすく, $\mathrm{FeO}_{4}$ 四面 体構造がより結晶に近い対称性の良い構造になり，そ の結果, 四極子分裂の值が小さくなったと考光られる. これらの事実は，ガラス構造に和いて， $\mathrm{Fe}^{3+-} \mathrm{O}^{2-}$ 結 合距離よりも， $\mathrm{O}^{2-}-\mathrm{Fe}^{3+-} \mathrm{O}^{2-}$ 結合角の方がより大き な分布（自由度）を持つといらことを示唆する。

Fig. 2 に扮いて， $440^{\circ} \mathrm{C} て ゙$ 熱処理した試料では，2 本の常磁性ピークに加えて磁気的に分裂した 4 本の弱

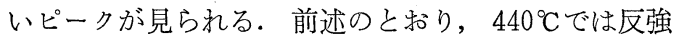
磁性の $\mathrm{BaFe}_{2} \mathrm{O}_{4}$ が現れる. したがって，これらの 4 本のピークは $\mathrm{BaFe}_{2} \mathrm{O}_{4}$ によるものである. 一方, 2 本の常磁性ピークは試料中に残存しているガラス相掠 よび $\mathrm{Ba}_{2} \mathrm{Fe}_{2} \mathrm{O}_{5}$ 結晶相によるものであり，ピークの強 度を考慮すると，この試料中では大部分はガラス相と して存在していることがわかる. 熱処理温度が $600^{\circ} \mathrm{C}$ になると磁気的に分裂したピークはさらに強度を増す。 この試料では $\mathrm{BaFe}_{2} \mathrm{O}_{4}$ 結晶は十分成長していると考 えられる.このスペクトルには依然として常磁性ピー クが現れているが，ピーク位置や四極子分裂の不明り ようさを考慮するとこれは $\mathrm{Ba}_{2} \mathrm{Fe}_{2} \mathrm{O}_{5}$ 結晶によるもの と考兄られ, それゆ光, この結晶は室温では常磁性で あると思わ礼る。

メスバゥアースペクトルから得られる種々のパラメ 一タのうち, 異性体シフトの熱処理温度による変化を Fig. 3 と示した. 図中，白丸はFig. 2 飞見られた常

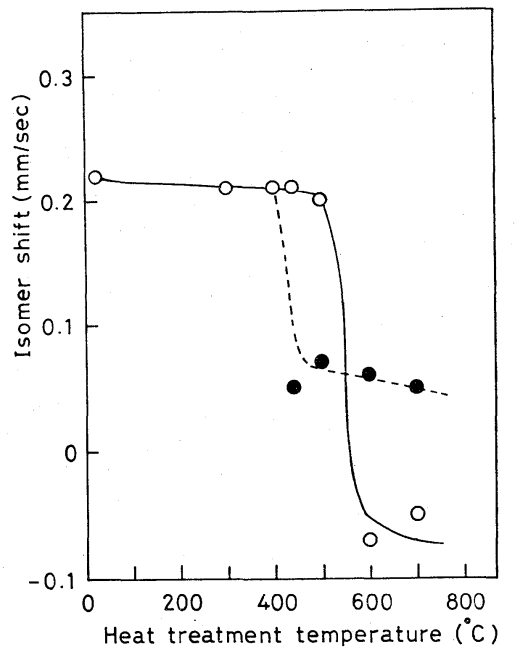

Fig. 3. Change on isomer shift of $\mathrm{Fe}^{3+}$ through the heat treatment process.

磁性ピークから求めたもの, 黒丸は磁気的分裂を受け たピークのらち低速度側から数觉て 2 番目之 5 番目の ピークから求めたものである. 眓から明らかなように, 熱処理温度が $400^{\circ} \mathrm{C}$ 付近までは異性体シフトに大きな 変化は見られないが, 結晶が現れ始める $440^{\circ} \mathrm{C}$ 付近か ら異性体シフトは急激に減少する。このことから，ガ ラス状態で存在する $\mathrm{Fe}^{3+}$ の局所構造と, $\mathrm{BaFe}_{2} \mathrm{O}_{4}$ 扝 よび $\mathrm{Ba}_{2} \mathrm{Fe}_{2} \mathrm{O}_{5}$ 結晶中のそれとは異なっていることが わかる.

ところで, 異性体シフトの值はスペクトルのピーク 位置から求めたものであるから，2 次ドップラーシフ トの効果を含んでいる. デバイ理論を用いた場合の 2 次ドップラーシフト $\Delta E / E$ は，次式で与兄られる.

$$
\frac{\Delta E}{E}=-\frac{9 k \theta_{\mathrm{D}}}{16 M c^{2}}\left\{1+8\left(\frac{T}{\theta_{\mathrm{D}}}\right)^{4} \int_{0}^{\theta_{\mathrm{D}^{\prime T}}} \frac{x^{3}}{e^{x}-1} d x\right\}
$$

ここで，kはボルツマン定数， $\theta_{\mathrm{D}}$ はデバイ温度， $M$ は原子 (イオン) の質量, $c$ は光速である. $T \gg \theta_{\mathrm{D}} / 2$ が成立する場合には，次の高温近似の式が成り立つ.

$$
\frac{\Delta E}{E}=-\frac{9 k \theta_{\mathrm{D}}}{16 M c^{2}}\left\{1+8\left(\frac{T}{\theta_{\mathrm{D}}}\right)^{2}\right\}
$$

後述するように，ガラスあるいは結晶中の $\mathrm{Fe}^{3+}$ によ

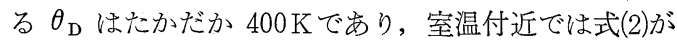
十分成立する.式(2)を $\theta_{\mathrm{D}}$ のみの関数と見なせば，こ の関数は $\theta_{\mathrm{D}}<2 T$ の範囲では単調増加する. したがっ て, $\theta_{\mathrm{D}}$ が小さい值の場合には式(2)怯負の絶対值が大 きい值をとり， $\theta_{\mathrm{D}}$ が大きいと逆に負の絶対值が小さ い值をとる、すなわち， $\theta_{\mathrm{D}}$ が小さい漂ど 2 次ドップ ラーシフトの効果は大きくなり，異性体シフトの值を 減少させるように㗢く.ところで, Komatsu と Soga は $50 \mathrm{SiO}_{2}-30 \mathrm{Na}_{2} \mathrm{O}-10 \mathrm{NiO}-10 \mathrm{Fe}_{2} \mathrm{O}_{3}$ ガラスからの $\mathrm{Ni}$ $\mathrm{Fe}_{2} \mathrm{O}_{4}$ 結晶の析出過程のメスバウアー効果測定から, 
Fig. 3 と同様に結晶化にともなって異性体シフトが単 調に減少することを見出し，これを $4 \mathrm{~s}$ 電子密度の差 と結び付けた。，一方，彼らは，無反跳分率の温度依存 性からガラス拉よび結晶のデバイ温度を求め, 前者が

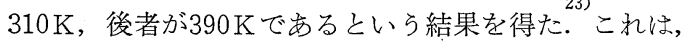
異性体シフトの変化が 2 次ドップラーシフトでは説明 できないことを示唆している．2 次ドップラーシフト は異性体シフトの大ささに比べて 1 ～2けた小さいと いう報告も㐫り, ここでは異性体シフトの違いは $\mathrm{Fe}$ の原子核位置に和故電子密度の違いに求めるべきで 要ると考皃た．原子核位置の電子密度がゼ口にならな いのは球対称の軌道を持つ $\mathrm{s}$ 軌道であるが，そのうち $1 \mathrm{~s} ， 2 \mathrm{~s}$ 和よび 3s 軌道は内殼に存在するため, その電 子密度は $3 \mathrm{~d}$ 軌道の電子密度が一定であれば一定であ ると考兄られ，結局異性体シフトに差を与兄るのは $4 \mathrm{~s}$ 電子密度である. Walker らはこの $4 \mathrm{~s}$ 軌道の寄与の 割合を考慮して，原子核位置の全電子密度 $|\psi(0)|^{2}$ を 次式で表現した。

$$
|\psi(0)|^{2}=2 \sum_{n=1}^{3}\left|\psi_{n \mathrm{~s}}(0)\right|^{2}+x\left|\psi_{4 \mathrm{~s}}(0)\right|^{2}-C
$$

$2\left|\psi_{n \mathrm{~s}}(0)\right|^{2}$ は $n \mathrm{~s}$ 軌道の電子密度である。るた，Cは 定数で, $C=11873 a_{0}^{-3}$ ( $a_{0}$ はボーア半径) の值が与兄 られている. Walker らは理論的計計算した電子密度 と異性体シフトの值とを結び付けた，その結果を用い て本研究の異性体シフトの実測值から $4 \mathrm{~s}$ 軌道の寄与 の割合を計算し，熱処理温度に対してプロットした結 果が Fig. 4 である. ガラス拉よび結晶中での $\mathrm{Fe}^{3+}$ O2-の結合は主としてイオン結合が支配していると考 えられるが，Fig.4 から明らかなように 4s 電子の一

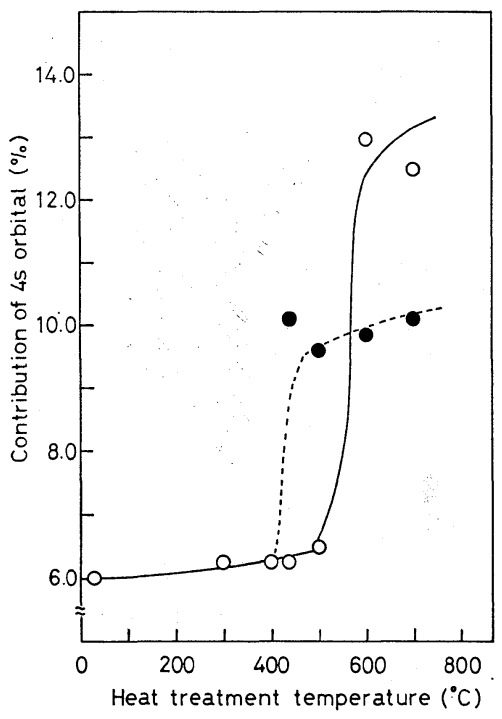

Fig. 4. Change on the contribution of $4 \mathrm{~s}$ orbital to $\mathrm{Fe}^{3+-} \mathrm{O}^{2-}$ chemical bond through the heat treatment process.
部が $\mathrm{Fe}^{3+}$ に局在化して，少し共有結合性も帯びてい る.扔そらく $4 \mathrm{~s}$ 電子の一部は $3 \mathrm{~d}$ 軌道と $\mathrm{sd}^{3}$ 混成軌 道を形成し, 酸素イオンを 4 配位で配位させているる のと思われる.この $4 \mathrm{~s}$ 電子は, 酸素イオンの $2 \mathrm{p}$ 軌 道の電子の一部が $\mathrm{Fe}^{3+}$ の $4 \mathrm{~s}$ 軌道に移ることにより 現れると解釈できるが， $\mathrm{Fe}^{3+}-\mathrm{O}^{2-}$ 結合距離が短くな るほどその頻度は増加するはずである。したがって， Fig. 4 に見られるよらなガラスからの結晶化にともな 万 $4 \mathrm{~s}$ 軌道の寄与の増加は, 結晶化化ともなう $\mathrm{Fe}^{3+}$ $\mathrm{O}^{2-}$ 結合距離の減少によるものであると推測される。

Fig. 5 は熱処理にともなら四極子分裂の変化を示し たものである. 四中の白丸と黒丸の区別は前述の Fig. 3 と同様で, 白丸瑺磁性ピークから求めたもの, 黒 丸は磁気的分裂を受けたピークから求めたものである.

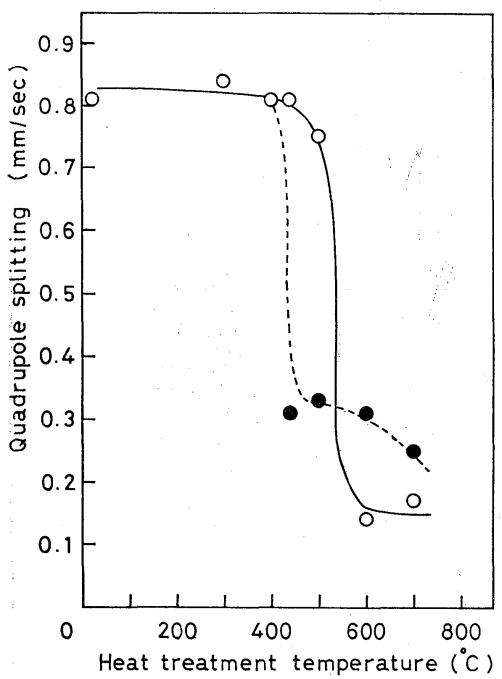

Fig. 5. Change on quadrupole splitting of $\mathrm{Fe}^{3+}$ through the heat treatment process.

特に後者は $i$ 番目のピーク位置を $v_{i}$ として，

$$
\text { Q.S. }=\frac{1}{2}\left(v_{1}-v_{2}-v_{5}+v_{6}\right)
$$

から計算した，四極子分裂の值も異性体シフトと同様, 結晶析出の直前まではほとんぞ一定であるが，結晶析 出後急激減少している． $\mathrm{Fe}^{3+}$ はスピソが $\mathrm{S}$ 状態で あるので，四極子分裂の変化は $\mathrm{O}^{2-}$ の配位状態の立 方対称からの逸脱を直接反映する。すなわち実験結果 は, $\mathrm{FeO}_{4}$ 四面体構造がガラスでは結晶に比べて幾何 学的にゆがんだ状態であることを示している.ところ で $\mathrm{BaFe}_{2} \mathrm{O}_{4}$ の四極子分裂の值は $0.3 \mathrm{~mm} / \mathrm{s}$ 付近にあ るが，このことは $\mathrm{BaFe}_{2} \mathrm{O}_{4}$ 結晶中で $\mathrm{Fe}^{3+}$ のますり の電場こう配の主軸 と, $\mathrm{Fe}^{3+}$ の作る内部磁場の方向 とが一定の角度をなしていることを表している. 700 ${ }^{\circ} \mathrm{C}$ で熱処理した試料の四極子分裂は $0.25 \mathrm{~mm} / \mathrm{s}$ であ ったが，これは $\mathrm{BaFe}_{2} \mathrm{O}_{4}$ について報告されている值 とよく一致している. 
さて Fig. 5 をFig. 3 と比較してみると, 結晶化の 段階での四極子分裂の変化は, 異性体シフトのそれに 比べてかなり大きくなっていることがわかる．定性的 に言えば, $\mathrm{Fe}^{3+-} \mathrm{O}^{2-}$ 結合距離の変化よりも, $\mathrm{O}^{2-}-$ $\mathrm{Fe}^{3+-} \mathrm{O}^{2-}$ 結合角の変化の方が大きいことが予想され る.

Fig. 6 は室温での内部磁場の変化をプロットしたも のである.ガラス状態では室温では常磁性であり内部 磁場は示さない.内部磁場は結晶化の始まる $440^{\circ} \mathrm{C}$ 付 近から現れる. 熱処理温度の増加にともない内部磁場 は上昇し， $600^{\circ} \mathrm{C}$ 付近で飽和に達する。この 飽和值は $474 \mathrm{kOe}$ であり， $\mathrm{BaFe}_{2} \mathrm{O}_{4}$ について報告されている值 $472 \mathrm{kOe}$ に注汸一致している。結晶化の初期段階では 内部磁場の值はこれより小さくなっているが，これは 結晶粒子が小さいためと考党られる. この上うな現象 は, ケイ酸塩ガラスからの $\mathrm{NiFe}_{2} \mathrm{O}_{4}$ の析出過程にお

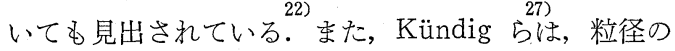
異なる $\alpha-\mathrm{Fe}_{2} \mathrm{O}_{3}$ の室温でのメスバウアースペクトル

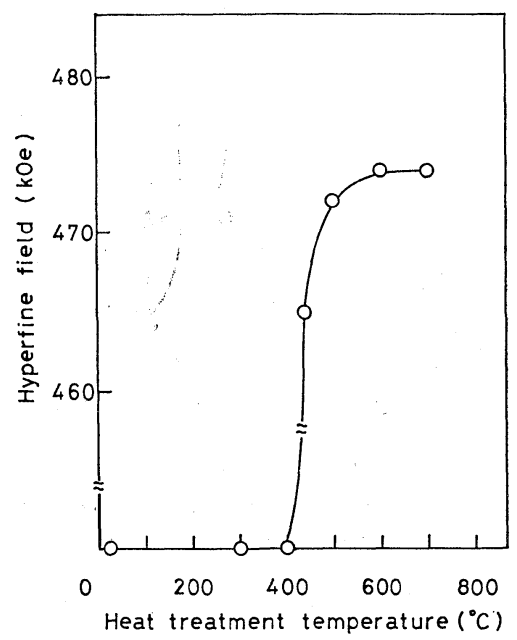

Fig. 6. Change on hyperfine field through the heat treatment process.

を測定し，粒径が大きくなるほど内部磁場が大きくな ることを観察している. したがって，Fig. 6 亿見られ る内部磁場の増加は, 反強磁性結晶 $\mathrm{BaFe}_{2} \mathrm{O}_{4}$ の成長 によるものと解釈できる. 粒径の減少にともなら内部 磁場の減少の原因としては, Komatsu らが述べてい る, 超常磁性と結びういた磁化の緩和時間の効果のほ か, 粒子の表面層の効果も考兄られる.すなわ方, 粒 径が小さいと, 非磁性の表面層の影響が大さくなるの で, 内部磁場がバルクの值よりも小さくなると予想さ れる。

\section{$3 \cdot 2$ 熱処理にともなう ESR スペクトルの変化}

実測された ESR スペクトルをFig. 7 に示した. 熱 処理前のガラスおよび $440^{\circ} \mathrm{C} て ゙$ 熱処理した試料のスペ

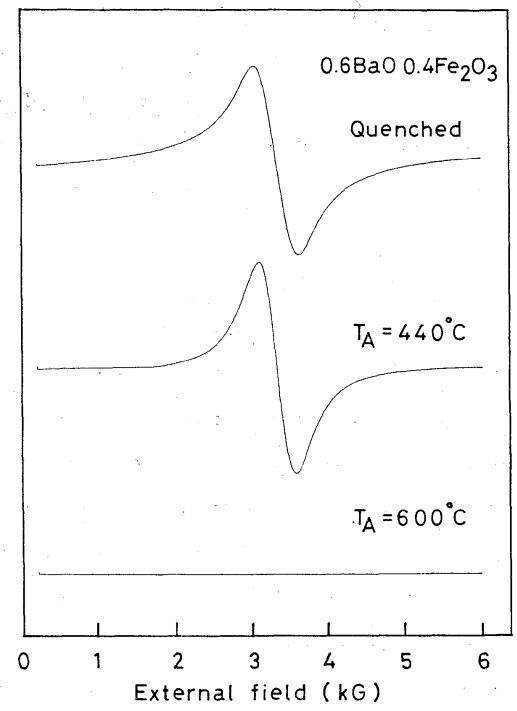

Fig. 7. ESR spectra of quenched, heat-treated at $440{ }^{\circ} \mathrm{C}$, and heat-treated at $600^{\circ} \mathrm{C} 0.6 \mathrm{BaO}$ $-0.4 \mathrm{Fe}_{2} \mathrm{O}_{3}$ glass.

クトルでは, $g=2.0$ 付近にのみ共鳴吸収が見られ， 局所的に鉄イオンは $\mathrm{Fe}^{3+}-\mathrm{O}^{2-}-\mathrm{Fe}^{3+}$ のスピン対を作

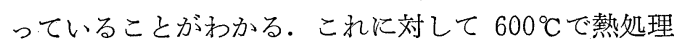
した試料では，このシグナルは消失している， $700^{\circ} \mathrm{C}$ で熱処理した試料でも同様の結果が得られた. そこで これら二つの試料についてシグナルの強度を增幅させ た結果が Fig. 8 である. 極めて弱いが $g=2.0$ 付近 にシグナルが観察される.これらの試料中では $\mathrm{BaFe}_{2}$ $\mathrm{O}_{4}$ と $\mathrm{Ba}_{2} \mathrm{Fe}_{2} \mathrm{O}_{5}$ が析出しているが，前者は反強磁性 であるため共鳴吸収は起らず Fig. 7 ではシグナルが 消失している.Fig. 8 に見られるシグナルは， $\mathrm{Ba}_{2} \mathrm{Fe}_{2}$ $\mathrm{O}_{5}$ に上るものと考光られる.

これらの ESR スペクトルから得られる線幅と $g$ 值

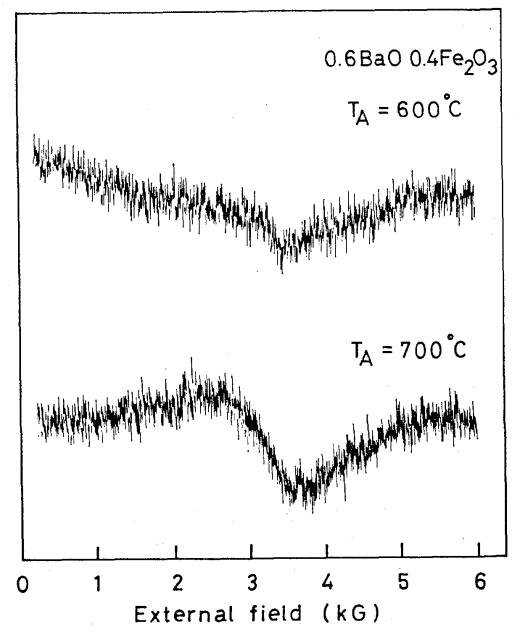

Fig. 8. ESR spectra of the specimens heattreated at $600^{\circ} \mathrm{C}$ and $700^{\circ} \mathrm{C}$. 


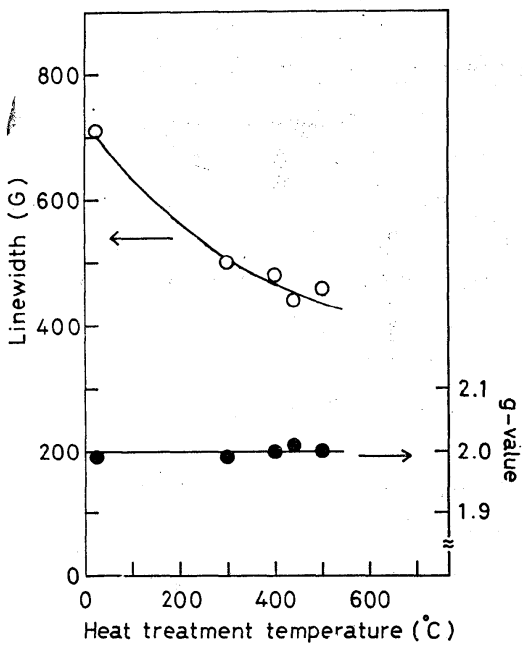

Fig. 9. Change on ESR linewidth and effective $g$-value through the heat treatment process.

の変化を示したるのが Fig. 9 である. 線幅は熱処理 温度の増加にともなって単調に減少している。一方, $g$ 值は熱処理温度にかかわらず一定であり，先の值は $g=2.00 \pm 0.01$ となった.

線幅の変化を定性的㼁論するには，次の Anderson-Weiss の氠が有効である.

$$
\Delta H=\frac{\frac{10}{3}\left(\Delta H_{p}\right)^{2}+\left(\Delta H_{H}\right)^{2}}{\Delta H_{e}}
$$

ここで $\Delta H$ は実測される ESR スペクトルの線幅であ り， $\Delta H_{p}, \Delta H_{e}, \Delta H_{H}$ は乞れぞれ磁気双極子相互作用, 超交換相互作用，および微細構造㲹起因する線幅であ る. $\Delta H_{H}$ に関しては, $\mathrm{Fe}^{3+}$ や $\mathrm{Mn}^{2+}$ のような $\mathrm{S}$ 状 態の磁性イオンを含んだ結晶に対して $10^{3} \mathrm{G}$ 程度のほ ぼ一定の值が得られている. そこで本研究の熱処理過 程に扮いて $\Delta H_{H}$ はほとんど变化しないと仮定できる。 したがって, Fig. 9 に見られる線幅の減少は, 磁気双 極子相互作用に対して相対的沿超交換相互作用が增加 することによると見なせる．ところでメスバウアース ペクトルの変化のところで見たように, 結晶析出が起 るまでのガラス中の鉄 イオンの 局所構造，すなわち $\mathrm{FeO}_{4}$ 四面体の構造には大きな変化は見られなかった。 それにもかかわらずESR スペクトルの線幅は約 $700 \mathrm{G}$ から約 $500 \mathrm{G}$ へときく変化している。このことは, ガラスが熱処理によって構造緩和を受け， $\mathrm{Fe}^{3+-} \mathrm{O}^{2-}-$ $\mathrm{Fe}^{3+}$ 結合角が変化したことを示すものと思われる. $\mathrm{Fe}^{3+}-\mathrm{O}^{2-}-\mathrm{Fe}^{3+}$ 結合角が変れば $\mathrm{Fe}^{3+}$ の $\mathrm{d}$ 軌道と $\mathrm{O}^{2-}$ の $2 \mathrm{p}$ 軌道の重なりの度合が変化するので，それに応 じて超交換相互作用も変化する. 熱処理の過程で $\mathrm{Fe}^{3+}$ $\mathrm{O}^{2-}-\mathrm{Fe}^{3+}$ 結合角が軌道の重なりを増すような方向へ と変化し, その結果線幅の減少が見られたのではない かと思われる。また， $\mathrm{Fe}^{3+-}-\mathrm{O}^{2-}-\mathrm{Fe}^{3+}$ 結合角が変れば
$\mathrm{Fe}^{3+}$ 同志の距離ひ変化するので磁気双極子相互作用 も変化する。この変化も線幅に影響を括よぼす。Van Vleck の式

$$
\Delta H_{p} \propto \sqrt{S(S+1)} r^{-3}
$$

を用いて計算すれば， $\mathrm{Fe}^{3+}-\mathrm{O}^{2-}-\mathrm{Fe}^{3+}$ が一直線上に並 んだときの $\Delta H_{p}$ は， $\mathrm{Fe}^{3+}-\mathrm{O}^{2-}-\mathrm{Fe}^{3+}$ が $90^{\circ}$ をなす場 合の0.35倍程度の值となる。いずれにせよ，Fig. 9 に 見られる線幅の減少は $\mathrm{Fe}^{3+-}-\mathrm{O}^{2-}-\mathrm{Fe}^{3+}$ 結合角の变化 によって説明できる。上のことから，0.6BaO-0.4 $\mathrm{Fe}_{2} \mathrm{O}_{3}$ ガラスの熱処理過程に関して次のように結論ら゙ けることができる、すなわち，結晶化が起るまでのガ ラスの構造緩和は， $\mathrm{FeO}_{4}$ 四面体はその構造を変えず, 主として $\mathrm{Fe}^{3+}-\mathrm{O}^{2-}-\mathrm{Fe}^{3+}$ 結合角が变化を受ける。結 晶化後は, $\mathrm{Fe}^{3+}-\mathrm{O}^{2-}$ 結合距離の減少就よび $\mathrm{FeO}_{4}$ 四 面体の立方対称性の向上が起る.

Fig. 9 飞は $g$ 值の変化子示されているが，前述のと 抢りこれは $g=2.00$ 付近の一定值をとる.この值は自 発磁化に軌道角運動量が寄与しない $\mathrm{Fe}^{3+}$ に対して妥 当な值である.

\section{4 結 論}

0.6 $\mathrm{BaO}-0.4 \mathrm{Fe}_{2} \mathrm{O}_{3}$ ガラスの熱処理過程を ESR お よびメスバゥアー分光法を用いて追跡し，次のような 結論が得られた。まず，ガラス中では鉄イオンはすべ て $\mathrm{Fe}^{3+}$ の形で存在し, 酸素イオンを 4 配位で配位し ている.このガラスからは反強磁性の $\mathrm{BaFe}_{2} \mathrm{O}_{4}$ が析 出するが，結晶化前のガラスの熱的構造緩和は主とし て $\mathrm{Fe}^{3+-} \mathrm{O}^{2-} \mathrm{Fe}^{3+}$ 結合角の変化で記述できると考えら れる. 結晶化の初期過程では $\mathrm{Fe}^{3+}-\mathrm{O}^{2-}$ 結合距離の減 少括よび $\mathrm{FeO}_{4}$ 四面体の立方対称性の向上が起り,や がて $\mathrm{BaFe}_{2} \mathrm{O}_{4}$ の結晶化へと移行した. 結晶成長にし たがって, $\mathrm{Fe}^{3+}$ の作る内部磁場が増加し, $474 \mathrm{kOe} て ゙$ 飽和に達した．粒子が小さい場合の内部磁場の值が小 さくなるのは, 超常磁性および表面層の效果で説明で きると思われる。

メスバウアー効果測定装置の使用ならびに助言に対 乙, 京都大学放射性同位元素総合センター, 五十棲泰 人博士に心から感謝の意を表します。

（昭和60年12月 4 日 第28回セラミック材料部門委員会䎲て譵演）

\section{参 考 文 献}

1) A. W. Simpson and J.M. Lucas, J. Appl. Phys., 42, 2181 (1971).

2) T. Egami, O.A. Sacli, A.W. Simpson, A. L. Terry and F.A. Wedgwood, J. Phys. C: Solid State Phys., 5, L261 (1972).

3) R.A. Verhelst, R. W. Kline, A.M. de Graaf and H. O. Hooper, Phys. Rev. B11, 4427 (1975).

4) J.P. Sanchez, J. M. Friedt, R. Horne and A.J. 
Van Duyneveldt, J. Phys. C: Solid State Phys., 17, 127 (1984).

5) S. K. Mendiratta, R. Horne and A. J. Van Duyneveldt, Solid State Commun., 52, 371 (1984).

6) E. M. Gyorgy, K. Nassau, M. Eibschütz, J. V. Waszczak, C. A. Wang and J.C. Shelton, J. Appl. Phys., 50, 2883 (1979).

7) Y. Syono, A. Ito and O. Horie, J. Phys. Soc. Jpn., 46, 793 (1979).

8) H. Laville and J.C. Bernier, J. Mater. Sci., 15, 73 (1980).

9) A. M. Van Diepen and Th. J.A. Popma, Solid State Commun., 27, 121 (1978).

10) E. J. Friebele and N.C. Koon, Solid State Commun., 14, 1247 (1974).

11) G. Ferey, F. Varret and J. M. D. Coey, J. Phys. C: Solid State Phys., 12, L531 (1979).

12) J.P. Renard, J. P. Miranday and F. Varret, Solid State Commun., 35, 41 (1980).

13）幸塚広光，大田陸夫，兽我直弘，材料， 35，73 (1986).

14) T. Komatsu, N. Soga and M. Kunugi, J. Appl. Phys., 50, 6469 (1979).

15）大田陸夫，木下俊哉，曾我直弘，粉体捛よび粉末治金， 32, 104 (1985).

16) P. Kantor, A. Revcolevschi and R. Collongues, J.
Mater. Sci., 8, 1359 (1973).

17）黒光祥郎, 森永健次, 柳ヶ瀬勉, 窯協, 92, 173 (1984).

18) Y. Goto and T. Takada, J. Amer. Ceram. Soc., 43, 150 (1960).

19) T. Yanagase, K. Morinaga, Y. Kuromitsu and S. Fuchigami, J. Non-Cryst. Solids, 56, 361 (1983).

20）黒光祥郎, 森永健次, 柳ヶ瀨勉, 窝業, 92, 562 (1984).

21) C. R. Kurkjian and E. A. Sigety, Phys. Chem. Glasses, 9, 73 (1968).

22) T. Komatsu and N. Soga, J. Appl. Phys., 51, 601 (1980).

23) T. Komatsu and N. Soga, J. Appl. Phys., 51, 5926 (1980).

24）佐野博敏, “メスバウアー分光学概論”, p. 58 (1972) 講 談社.

25) L. R. Walker, G. K. Wertheim and V. Jaccarino, Phys. Rev. Letters, 6, 98 (1961).

26) C. Do-Dinh, E.F. Bertaut and J. Chappert, J. de Phys., 30, 566 (1969).

27) W. Kündig and H. Bömmel, Phys. Rev., 142, 327 (1966).

28) P.W. Anderson and P. R. Weiss, Rev. Mod. Phys., 25, 269 (1953).

29) J. H. Van Vleck, Phyṣ. Rev., 74, 1168 (1948). 